\title{
Motivation among hospital volunteers: an empirical analysis in Portugal
}

\author{
Marisa R. Ferreira • Teresa Proença • \\ João F. Proença
}

\begin{abstract}
The purpose of this paper is to identify the different types of motivations in hospital volunteers. We present a literature review about different types of motivation and we collect data from hospital volunteers through a questionnaire. Four different motivation categories are identified: development and learning, altruism, career recognition and belonging and protection. The main motivations expressed are development and learning, followed by altruism. Belonging and protection, followed by career recognition are the least cited motivations. Career recognition is negatively correlated with age, and belonging/ protection is negatively correlated with education. That is, younger volunteers present more career recognition motives and less educated volunteers have more from protection and belonging. This study encompasses hospital volunteers and their motivations. The paper is useful to policy makers aiming to develop targeted approaches to attracting and retaining volunteers.
\end{abstract}

Keywords Hospital volunteers $\cdot$ Motivations $\cdot$ Development and learning

\section{Introduction}

"From the end of the 1970s onwards, interest in the non-profit (NPO) sector started to grow" (Borzaga and Santuari 2003: 32). Interest in this sector progressively increased, 
particularly due to its ability to provide new social services, its job creation potential and its capacity to promote social cohesion (Borzaga and Santuari 2003). Recently the sector has witnessed spectacular growth in numbers and scope, and its organisations are active in an enormous spectrum of activities - from welfare services to leisure pursuits, from political pressure groups to arts and hobby groups (Lewis 2001). "The non-profit sector has transformed itself from the somewhat informal and inchoate world of philanthropy and charities to a more rationalized world where non-profit organisations model themselves on business corporations or government agencies" (Musick and Wilson 2008: 6). There is clearly a growing concern with the management resulting from recent changes in NPOs and in their environment evidenced by the fact that it is increasingly seen as an important area for them, however, this does not mean that there is not much resistance on this approach (Ferreira 2004). In countries where the non-profit sector is well established NPOs are becoming more entrepreneurial, experimenting with innovative ways of raising funds and designing new evaluation tools (OECD 2003).

The contribution of social or non-profit enterprises has been enormous and diverse and since they are connected to the marketplace it has become important for marketers (Briggs et al. 2010) and the use of marketing concepts in a broader range is not new (Yavas and Riecken 1985). However, the increase in the number of third sector organisations has not been accompanied by an equal growth in the availability of resources, therefore, NPOs are taking a more practical approach and are using techniques and processes which are more frequently seen in the for-profit sector (Randle and Dolnicar 2009). Sometimes they are less clear about the meaning of marketing, connecting it primarily with fundraising and not with communicating with clients or volunteers (Pope et al. 2009). Because marketing and public policy is a subfield that involves difficult research problems involving behavioural effects there are still some questions to address, including the way people can be persuaded through the use of social advertising or other social marketing tools (Bloom 1997; Wei et al. 2012; Wymer 2012). Unexpectedly, marketing role in volunteer recruitment has been largely overlooked (Yavas and Riecken 1985).

NPO clients such as homeless or sick people can be identified as the final beneficiaries, although in our work we concentrated on the volunteers of these organisations. We consider volunteers as NPOs stakeholders (Ben-Ner and Hoomissen 1991; Braga and Carvalho 2010) since they can be understood as a group that affects or can be affected by organizations' actions (Freeman 1984; Hsieh et al. 2008) and can even be considered as strategic stakeholders since volunteers can influence the achievement of NPOs objectives (Frooman 1999). According to Freeman (1984), organisations must develop strategies for each stakeholders group, without forgetting that this is dynamic process (Hsieh et al. 2008), so understanding volunteers' motivations is essential to NPOs.

Volunteering has long been under-estimated, under-researched and undervalued, and only recently has the importance and value of volunteering begun to be recognised (Alfansi and Atmaja 2009). At the same time, the need for volunteers is unquestioned (Burns et al. 2006, 2008). Volunteers make considerable contributions to supporting communities at various levels through an abundant variety of activities (e.g. recreational activities in nursing homes, coaching kids in local sport clubs, support networks for the homeless, counselling, assisting major sports and cultural events, etc) (Cuskelly et al. 2006). Nearly 39.5 million people in FTE (full time employment) are employed in the non-profit sector (excluding traditional co-operatives) in the 35 countries studied by the 
Johns Hopkins Comparative Non-profit Sector Project. The non-profit sector employs $3.6 \%$ of the working-age population, representing $7.3 \%$ of non-agricultural employment and $46 \%$ of public sector employment (OECD 2003). There is some data about volunteering in Europe in the work of Marcuello et al. (2009). In the populations of European countries we can see that, for example, Sweden has around $56 \%$ who are volunteers, Holland $49 \%$ and Great Britain $42 \%$. These are the highest values presented in this study, and the average is $27 \%$. On the other hand, those with the lowest percentages of volunteering are Russia with $8 \%$, Ukraine with $13 \%$ and Poland with $14 \%$. Also with low values are Portugal with $16 \%$ volunteers, and Spain with $18 \%$. In the U.S.A. these values reach $50 \%$ (Wilson and Pimm 1996). In Portugal, Franco et al. (2005) show that the civil society sector is an economic force and it engages nearly a quarter of a million full-time equivalent workers, nearly $70 \%$ in paid positions and the remainder as volunteers. According to these authors this represents about $4.2 \%$ of the country's economically active population and about $5 \%$ of its non-agricultural employment. We can also analyse volunteering according to the sector.

Our research aims to understand volunteers' motivations in order to better encourage and retain them. We review the various motivations associated with volunteer work, and the main models, frameworks and tools used to explain and measure those motivations. We used 304 volunteers from 19 different Portuguese organisations that work with hospitals to test the kind of motivations they have. The results of the study are presented and we conclude by considering some implications for volunteer organisations and outlining directions for future research.

\section{Background}

\subsection{Motivations}

To better understand how to attract and retain volunteers, identifying the key motives of individual volunteers is crucial (Bussell and Forbes 2002). Theories on volunteer motives have been a central point in recent research, although additional research is required to identify primary reasons and motives for volunteering (Burns et al. 2006; Briggs et al. 2010). According to Esmond and Dunlop (2004) the first research in volunteer work appeared in the seventies, and altruism was one of the first motives identified (Tapp and Spanier 1973). In the eighties the volume of research on volunteer motivation grew (Esmond and Dunlop 2004) and produced the distinction between altruistic and egoistic motivations (Horton-Smith 1981; Phillips 1982). Some researchers contend that people have more than one reason for volunteering (Okun et al. 1998). The bipartite model (Frisch and Gerrard 1981) posits that people are motivated to volunteer by concerns for others (altruistic motives) and self (egoistic motives). So they consider motives dealing with the expression of personal values (e.g. helping those less fortunate) as altruistic motives, while other motives (e.g. developing social contacts) as self-serving motives. Until this moment the literature categorizes motivations based on models with two or three factors.

In 1991 Cnaan \& Goldberg-Glen identified a number of gaps in the literature on volunteer's motivations, referring to its descriptive prevalence and the absence of relationships between the different motivations. These authors consider a one factor 
model to be most appropriate to explaining volunteers' motivations (Cnaan and Goldberg-Glen 1991; Farrell et al. 1998).

The multi-factorial model was developed by Clary et al. (1998), and has as its main objective understanding the reasons, purposes, plans and goals that characterize the phenomenon of volunteering. They take a functionalist approach and classify motivations as follows: value, i.e. the chance for a volunteer to express his or her own values, knowledge and abilities; understanding, i.e., the opportunity of new learning experiences; social, i.e. the possibility to be with friends or to make new friends; career, related to the improvement of professional career through the voluntary work; protective, offering an alternative to negative feelings; and, finally, enhancement, related to their self-esteem and ego. This is, perhaps, one of the most complete categorisations in the literature (Ferreira et al. 2008).

Other researchers have classified volunteer motivations into intrinsic and extrinsic motivations (Raman and Pashupati 2002; Meier and Stutzer 2004). Volunteers receive an internal reward as direct result of their activity, and because they enjoy helping others and do not expect any (material) reward this is intrinsic motivation; on the other hand extrinsic motivation is where helping others is secondary, since volunteers expect external benefits or payoffs (Meier and Stutzer 2004) meaning that they are doing an activity for instrumental reasons (Meyer and Gagné 2008). Some consider the prime motivation to be a sense of duty or responsibility to a local community, and this prototype might often be embedded in a religious tradition of benevolence and altruism (Hustinx and Lammertyn 2003).

Figure 1 shows the above-mentioned evolution of motivations categories, and the colour gradation illustrates this evolution and expansion. Dashed lines around the concepts indicate that they are not completely closed and rigid, but that they are permeable and can be applied in different contexts.

\subsection{Measuring volunteers' motivations}

Recent research has focused on identifying volunteerism functions or on reasons that lead individuals to volunteer. Many tools have been used to determine and to explain these motivations (Trogdon 2005). In some cases researchers have adapted or have created specific tools for this area such as the Volunteer Functions Inventory (VFI), which allows a motivation profile of six different functions-value, understanding, social, career, protective and enhancement (Clary et al. 1998; Okun et al. 1998; Chacón and Vecina 1999; Allison et al. 2002; Okun and Schultz 2003; Papadakis et al. 2004;

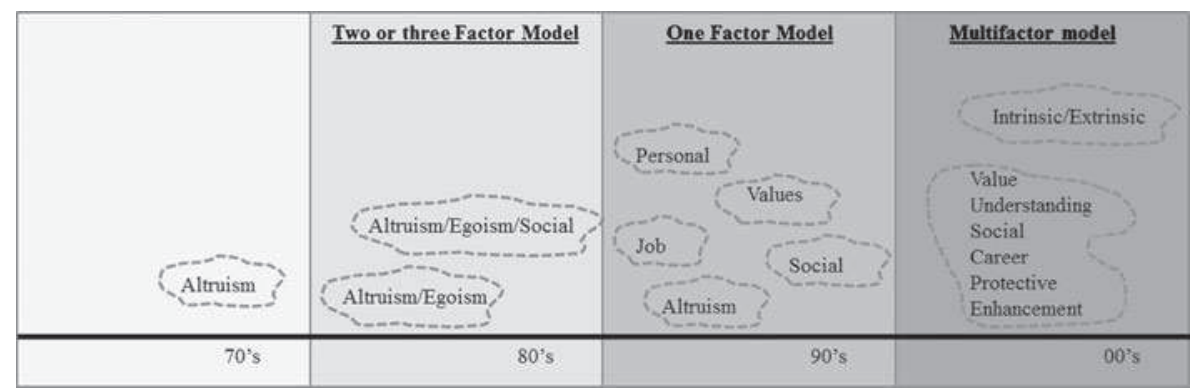

Fig. 1 Models on volunteers' motivations 
Trogdon 2005; Celdrán and Villar 2007; Yoshioka et al. 2007). This functional analysis considers that acts of volunteerism may seem fairly similar and respondents rate the importance of listed reasons for volunteering. However, there may be important differences in the motivational processes and these functions will be able to reflect the differences (Clary et al. 1998).

Another tool - the Recreation Experience Preference Scale (REP)—was used by Cuskelly and Harrington (1997) to capture the benefits of being a volunteer and (in the original version) identify leisure motivations (Manfredo et al. 1996). Next on our list is the Special Events Volunteer Motivation Scale (SEVMS), which studies special events and considers four motivation components-purposive, solidary, external traditions and commitments (Farrell et al. 1998). The first component is the desire to do something useful and contribute to the community and the event; the second component involves incentives related to social interaction; the third component expresses motivations related to family traditions and the use of free time; the fourth component links incentives that relate external expectations and personal skills to volunteering commitments (Farrell et al. 1998; Slaughter and Home 2004). In the work of Grano et al. (2008) we find the Motivation to Volunteer Scale (MVS) tool in which each item represents possible motives for volunteering and can be grouped in six different categories: intrinsic motivation, integrated regulation, identified regulation, introjected regulation, external regulation and amotivation.

The main reason for this study is to examine the configuration of volunteers' motivation. Our differentiating elements are connected to volunteers' working area and their nationality, i.e. we want to evaluate the motivations of Portuguese volunteers that work only in the health area (particularly in hospitals) and test whether their motivations are similar or different from the motivations identified in the literature, especially those identified by Clary et al. (1998). We seek to achieve a better understanding of hospital volunteers and what kind of motivations they have, especially those who have some interaction with patients and their families, and we will verify whether any significant differences can be identified on the basis of demographic attributes (namely age, participation in years, hours/week, income and education).

\section{The research}

\subsection{Sample}

We considered the set of volunteers that perform their activities in hospitals as one group. These volunteers had to belong to a NPO and have close contact with the final beneficiaries of the hospital, in this case patients and/or their familiars. Using data from INE (2001) and the National Health Department we compiled a list of the 108 public hospitals in Portugal, which have diverse legal configurations and are spread throughout the country. At this point we did not know which hospitals had auxiliary volunteers. We contacted all the hospitals by telephone and learned that 14 of them did not have volunteers. We did not get any information from 25 hospitals, leaving a total of 69 hospitals that we could identify as having volunteers. In this paper we present data from 19 different NPO's working in 19 hospitals. The participants belong to 19 organisations that work voluntarily with hospitals, supporting patients and their 
families. In total, 327 volunteers participated in the survey. We had 304 usable responses, since some of the questionnaires were not complete.

The majority of the participants are part-time volunteers and dedicate, on average, $6 \mathrm{~h}$ per week to their volunteer work. Participants range in age from 18 to 85 years $(M=57$, $S D=15)$ but they are mainly over 52 years-old; are women $(84 \%)$ and retired $(52.6 \%)$. It is important to note that gender differences might bring several implications in terms of management (Lee and Won 2011; Wymer 2012) and its responsiveness and adaptation to gender differences can increase volunteer retention (Wymer 2011). In Table 1 we see data related to monthly income, work situation, gender, civil state, education and age. We note that the monthly income is fundamentally around two categories (between 1000 and 2000 euros). If we consider recent data about education in Portuguese residents aged 55 years or more (INE 2005), we see that $62 \%$ have basic education, $5 \%$ have earned a college degree and $4 \%$ have finished high school, so the volunteers in this study clearly present higher levels of education since $25 \%$ have a college degree and $20 \%$ have finished high school, which is consistent with education as a strong predictor of volunteering (Burns et al. 2008; Musick and Wilson 2008). According to the same authors, education raises consciousness of social problems, encourages people to be more analytical and more critical of social conditions, and provides more information about the world around them. Volunteers' higher levels of education are also shown in previous works (Yavas and Riecken 1985; Ferreira et al. 2012).

\subsection{Measures and procedures}

A survey instrument was prepared to measure volunteers' motivations. Questions were rated on a seven point Likert scale. The issues covered in the scales emerged as a result of the literature review, we used an adapted version of the Volunteer Function Inventory (VFI), ${ }^{1}$ an instrument designed to measure the functions served by volunteerism created by Clary et al. (1998). Literature reviews on the scales to measure volunteers' motivation presents several studies using the same instrument (Clary et al. 1998; Papadakis et al. 2004; Trogdon 2005; Yoshioka et al. 2007) which increases our confidence in VFI and allows comparisons of our results with others works. The VFI is an inventory that includes a set of items that reflects the psychological and social functions of volunteerism identified by the conceptual analysis identified by the authors. It follows a functionalist approach of motivation and classifies motivations into value, understanding, social, career, protective and enhancement.

\section{Results}

We were interested to see whether volunteers' motivations could be reduced and grouped into a smaller number of factors. The first step was to do a factor analysis applied to the dataset of 30 items that belong to VFI. "Prior to the extraction of factors, a Bartlett test of Sphericity and the KMO measure of sampling adequacy confirmed that there was sufficient correlation among the variables to warrant the application of factor analysis.

\footnotetext{
${ }^{1}$ We changed items 17 and 23 because we considered that the original text was not very adequate for the Portuguese reality.
} 
Table 1 Monthly income, work situation, gender, civil state, education and age

\begin{tabular}{|c|c|c|c|}
\hline & & Frequency & Percent \\
\hline \multirow[t]{6}{*}{ Monthly income } & Up to $1000 €$ & 68 & 22.4 \\
\hline & {$[1000 €-2000 €]$} & 73 & 24.0 \\
\hline & [2000€-3000€] & 30 & 9.9 \\
\hline & more than $3000 €$ & 4 & 1.3 \\
\hline & Missing & 129 & 42.4 \\
\hline & Total & 304 & 100.0 \\
\hline \multirow[t]{8}{*}{ Work situation } & Full time & 40 & 13.2 \\
\hline & Part-time & 8 & 2.6 \\
\hline & Unemployed & 25 & 8.2 \\
\hline & Student & 15 & 4.9 \\
\hline & Retired & 160 & 52.6 \\
\hline & Other & 21 & 6.9 \\
\hline & Missing & 35 & 11.5 \\
\hline & Total & 304 & 100.0 \\
\hline \multirow[t]{4}{*}{ Gender } & Masculine & 34 & 11.2 \\
\hline & Feminine & 256 & 84.2 \\
\hline & Missing & 14 & 4.6 \\
\hline & Total & 304 & 100.0 \\
\hline \multirow[t]{6}{*}{ Civil state } & Single & 40 & 13.2 \\
\hline & Married & 162 & 53.3 \\
\hline & Divorced & 29 & 9.5 \\
\hline & Widowed & 48 & 15.8 \\
\hline & Missing & 25 & 8.2 \\
\hline & Total & 304 & 100.0 \\
\hline \multirow[t]{7}{*}{ Education } & Basic education & 67 & 22.0 \\
\hline & $9^{\circ}$ to $11^{\circ}$ grade & 34 & 11.2 \\
\hline & High school & 62 & 20.4 \\
\hline & College degree & 76 & 25.0 \\
\hline & Pos-grad & 12 & 3.9 \\
\hline & Missing & 53 & 17.4 \\
\hline & Total & 304 & 100.0 \\
\hline \multirow[t]{6}{*}{ Age } & $18-34$ years & 26 & 8.6 \\
\hline & $35-51$ years & 38 & 12.5 \\
\hline & $52-68$ years & 145 & 47.7 \\
\hline & 69-85 years & 60 & 19.7 \\
\hline & Missing & 35 & 11.5 \\
\hline & Total & 304 & 100.0 \\
\hline
\end{tabular}

In order to simplify the factor pattern, a varimax rotation was conducted" (Alfansi and Atmaja 2009: 314). The next step in a factor analysis is to decide the number of factors to extract, and as our criteria we consider eigenvalues greater than 1 , factor loadings greater 
than 0.5 and values for Kaiser-Meyer-Olkin (KMO) greater than 0.7 (Hair et al. 1998). We use Cronbach's alpha as the measure of internal consistency reliability and values greater than 0.8 to indicate a very good internal consistency (Pestana and Gageiro 2003).

Our initial analysis showed that a small number of items had unsatisfactory loadings, either because they were too low or because loadings were spread across more than one factor. An iterative process not including unsatisfactory items in different combinations yielded a more satisfactory pattern of loadings and more meaningful factors. This optimal solution was achieved after taking out five items from the analysis (loadings less than 0.5): volunteering makes me feel important (item 5), doing volunteer work relieves me of some of the guilt over being more fortunate than others (item 11), I feel compassion toward people in need (item 16), volunteering lets me know more people (item 17) and I can do something for a cause that is important to me (item 22).

Table 2 shows the new rotated matrix and the eigenvalues suggest a four-factor solution. The end of Table 2 presents the percentage of variance in the full set of the items that can be attributed to the four factors. The cumulative value of total variance explained by the four-factor solution is $57.7 \%$ and the value for $\mathrm{KMO}$ is also good (0.9). Thus, a model with four factors was considered to be adequate to represent the data. In Table 5 (Appendix 1) we can see that the value for Cronbach Alpha is very good (0.909) indicating high homogeneity and internal consistency. The values of the internal consistency of each component are 0.896 for component 1; 0.867 for component 2; 0.851 for component 3 which means that these components have a good internal consistency, although component 4 has a value of 0.601 which means that its internal consistency is weak.

The first component, comprising 9 items in total, has loadings that vary from 0.597 to 0.796 . The second component has 9 items and loadings are similar to component 1 . The third component includes 5 items with strong loadings ranging from 0.712 to 0.814. The fourth component comprising 2 items has also powerful loadings.

In the light of the factor loadings presented in Table 2, and following the functionalist approach of motivations (Clary et al. 1998) and Maslow's theory of human needs $(1943,1987)$ we decided to build a four-fold codification scheme. The four categories are: development and learning (component 1), belonging and protection (component 2), career recognition (component 3 ) and altruism (component 4)

Summary descriptive statistics for the 4 motivations categories are presented in Table 3. The highest motivation scores were recorded for development and learning (5.5 points on the $0-7$ point scale) and altruism (5.2 points). Career recognition motivation falls below the scale mean while belonging and protection is near the scale mean.

Table 4 presents relationships between the different types of motivations and some demographic attributes, namely age, participation in the organisation (in years), hours per week dedicated to the organisation, income and education. The first striking feature of these results is the uniformity; only a small number of correlations are statistically significant and those that are significant reflect mostly weak correlations, one of them less than 0.2 in magnitude and another one slightly greater than 0.2 . The highest correlation is only -0.277 . We can also see a negative correlation between education and belonging and protection motivation, which means that volunteers with higher levels of education have a negative correlation with the belonging and protection motivation. 
Table 2 Rotated component matrix

\begin{tabular}{|c|c|c|c|c|}
\hline & \multicolumn{4}{|c|}{ Component } \\
\hline & 1 & 2 & 3 & 4 \\
\hline $\begin{array}{l}\text { 12. I can learn more about the cause for which I am } \\
\text { working }\end{array}$ & 0.796 & & & \\
\hline $\begin{array}{l}\text { 14. Volunteering allows me to gain a new perspective } \\
\text { on things }\end{array}$ & 0.729 & & & \\
\hline 25. I can learn how to deal with a variety of people & 0.718 & & & \\
\hline 27. Volunteering makes me feel better about myself & 0.713 & & & \\
\hline 26. Volunteering makes me feel needed & 0.702 & & & \\
\hline $\begin{array}{l}\text { 18. Volunteering let me learn things through direct hands } \\
\text { on experience }\end{array}$ & 0.637 & & & \\
\hline 30. I can explore my own strengths & 0.615 & & & \\
\hline 19. I feel it is important to help others & 0.611 & & & \\
\hline 13. Volunteering increases my self-esteem & 0.597 & & & \\
\hline 9. By volunteering I feel less lonely & & 0.755 & & \\
\hline $\begin{array}{l}\text { 7. No matter how bad I've been feeling, volunteering helps } \\
\text { me to forget about it }\end{array}$ & & 0.701 & & \\
\hline $\begin{array}{l}\text { 20. Volunteering helps me work through by own personal } \\
\text { problems }\end{array}$ & & 0.637 & & \\
\hline 24. Volunteering is a good escape from my own troubles & & 0.617 & & \\
\hline 23. Volunteering makes me have more friends & & 0.611 & & \\
\hline 2. My friends volunteer & & 0.611 & & \\
\hline 29. Volunteering is a way to make new friends & & 0.595 & & \\
\hline 6. People I know share an interest in community service & & 0.589 & & \\
\hline 4. People I'm close to want me to volunteer & & 0.532 & & \\
\hline $\begin{array}{l}\text { 10. I can make new contacts that might help my business } \\
\text { or career }\end{array}$ & & & 0.814 & \\
\hline 28. Volunteering experience will look good on my résumé & & & 0.778 & \\
\hline 15. Volunteering allows me to explore different career options & & & 0.771 & \\
\hline $\begin{array}{l}\text { 21. Volunteering will help me to succeed in my chosen } \\
\text { profession }\end{array}$ & & & 0.770 & \\
\hline $\begin{array}{l}\text { 1. Volunteering can help me to get my foot in the door at a } \\
\text { place where I would like to work }\end{array}$ & & & 0.712 & \\
\hline 3. I am concerned about those less fortunate than myself & & & & 0.678 \\
\hline $\begin{array}{l}\text { 8. I am genuinely concerned about the particular group } \\
\text { I am serving }\end{array}$ & & & & 0.667 \\
\hline Eigenvalue & 8.125 & 3.220 & 1.784 & 1.297 \\
\hline Variance Explained in \% & 32.499 & 12.880 & 7.136 & 5.188 \\
\hline Total Variance Explained in \% & & & & 57.7 \\
\hline KMO & & & & 0.9 \\
\hline Bartlett's Test Approx. Chi-Square & & & & 2843.1 \\
\hline $\mathrm{df}$ & & & & 300.0 \\
\hline Sig. & & & & 0.0 \\
\hline
\end{tabular}


Table 3 Descriptive statistics

\begin{tabular}{lllll}
\hline & Minimum & Maximum & Mean & Std. deviation \\
\hline Component 1-M1 & 1.0 & 7.0 & 5.5 & 1.1 \\
Component 2-M2 & 1.0 & 7.0 & 3.7 & 1.4 \\
Component 3-M3 & 1.0 & 7.0 & 2.0 & 1.4 \\
Component 4-M4 & 1.0 & 7.0 & 5.2 & 1.6 \\
\hline
\end{tabular}

\section{Discussion}

In this study we are concerned with volunteers' motivations, and upon analysing the quantitative data the results clearly show and allow us to catalogue four motivational factors for volunteering. What follows is a discussion of each of these motivations and of the correlations previously identified.

Many individuals consider that volunteerism will have a positive impact in their learning process, enrichment and broadening horizons (Trogdon 2005) and they regard it as an opportunity to learn, increase their knowledge about society and develop social skills (Kemp 2002) as well as learn more about a specific cause and gain new perspectives. They believe that they will get an opportunity to use their skills and pass them on to others (Rhoden et al. 2009) and gain substantial amount of experience (Kemp 2002). At the same time volunteers want to increase their self-esteem and feel better about themselves (Edwards 2005); Rhoden et al. (2009) found that volunteers aim to keep themselves mentally and physically active, expecting to "recharge their batteries" and to be able to 'switch off' from daily life. These reasons belong to component 1 and we classify them as the Development and Learning category.

Component 2 is classified as the Belonging and Protection category since it includes motivations related with social interaction, friendship, affection and love (Latham 2007), with active involvement and the acquisition of positive experience (Rhoden et al. 2009). Our study found elements such as making new friends, meeting people (Anderson and Shaw 1999), interacting with others (Edwards 2005). Some motives relate to factors outside of volunteers' immediate control, including being appreciated by family and friends, and in some cases they might be asked to volunteer by family and friends or they did so because their family or friends were also volunteering

Table 4 Pearson correlations

\begin{tabular}{llllr}
\hline & M1 & M2 & M3 & M4 \\
\hline Age & -0.106 & 0.112 & $-0.277^{* *}$ & 0.021 \\
Participation (years) & -0.079 & 0.088 & -0.107 & 0.072 \\
Hours/Week & -0.052 & 0.055 & -0.069 & 0.054 \\
Income & -0.107 & -0.095 & -0.128 & 0.069 \\
Education & -0.076 & $-0.182^{* *}$ & 0.090 & 0.067 \\
\hline
\end{tabular}

**Correlation is significant at the 0.01 level (2-tailed)

*Correlation is significant at the 0.05 level (2-tailed) 
(Edwards 2005). We can refer to relational objectives and motivations which may express a need to compensate for a deficiency or loss of relationships, for example, according to Prouteau and Wolff (2008), widowed persons more frequently report this kind of motivation because the loss of a spouse impels them to develop new personal relationships.

Volunteers may also have expectations of tangible rewards or benefits associated with volunteerism, meaning that they want to increase their own welfare (Batson et al. 2002). Rewards and benefits assume different forms, and may be related to Career Recognition - component 3. Volunteers aim to make business contacts and improve their CV/résumé in order to increase their employability, gaining experience beneficial to full time work (Rhoden et al. 2009). Others see an opportunity to continue their connection to previous activity, for example according to Kim et al. (2007) many players turn to volunteering in order to continue their involvement with sport after their playing days are over.

Motivations related to Altruism - component 4 are the most frequently cited in the literature. There is a remarkable lack of agreement over what is meant by altruism (Monroe 1996). According to Monroe (1996) altruism is a behaviour that will benefit others, even when this involves eventual sacrifice to the welfare of the actor. According to Batson et al. (2002) altruism's ultimate goal is to increase the welfare of one or more individuals. One important source of altruism is empathic emotion, and empathy means other-oriented feelings congruent with the perceived welfare of another person (Batson et al. 2002). Often altruism is at the centre of volunteer motivations research, and has sparked controversy both for and against (Trogdon 2005). Altruism is a primary impetus for voluntary behaviour (Soupourmas and Ironmonger 2002; Burns et al. 2006, 2008) and concern with others characterizes this category.

We can see that there is a negative correlation between age and motivation related to career, which means that older volunteers tend to not be motivated by career recognition. Studying the relationship between age and volunteer motives (using VFI), Okun and Schultz (2003) find that age was positively related to social volunteer motivation and inversely related with career and understanding volunteer motivation. If we look closely at Table 1 we notice that the age group with the largest representation lies between 52 and 68 years $(47.7 \%)$ followed by the age group between 69 and 85 years $(19.7 \%)$, while the work situation most referenced is retired $(52.6 \%)$, so it seems clear that this group of volunteers is not connected with career recognition motivation because their career has ended or very near the end. Thus, the motivations of these volunteers will be of another nature, as stated previously. We can, also, observe a negative correlation between education and motivation related to belonging and protection, i.e. there is a negative correlation between higher levels of education and motivations related to belonging and protection. Surprisingly, the work of Wei et al. (2012) demonstrated that education was not related to volunteerism, although "it is likely that more schooling means people will be more self-confident, more secure, more knowledgeable about social issues, more aware of social problems and ways of tackling them (...)" (Musick and Wilson 2008: 75). So, motivations cataloged as belonging and protection covering aspects related to loneliness, friendships or personal problems are less important to these volunteers, since education appears to have a profound effect on volunteerism (Burns et al. 2008). 
Finally, "the field in which one operates is determined by a self-evident affinity with shared ideologies, religious convictions, and collective identities" (Hustinx and Lammertyn 2003: 177), and it is significant to mention that all these volunteers work in hospitals supporting patients and their families.

\section{Conclusion}

This paper discusses the motivations of volunteer work. If volunteers have no monetary reason for joining or staying with an organisation, it is important for the organisation to be aware of their main motives. Lately the role of social or non-profit organisations has gained great significance, and since they are in the marketplace this has become significant for marketers. Despite the resistance that organisations have to applying management and marketing tools to their routine, the fact is that they have a key role. Looking to volunteers as important NPO stakeholders might be imperative, since this will allow creation of value to an organisation through the identification and comprehension of volunteer motivations and these show up in the adoption of marketing practices of businesses in the non-profit sector. Whether practices such as market orientation or customer relationship management result in enhanced societal outcomes is now a concern, because non-profit organisations with more effective marketing efforts might actually be diverting resources from organisations that have much more impact and many more stakeholders (Briggs et al. 2010).

As illustrated in this study, volunteers are seeking development and learning, since this appears as the motivation with the greatest importance. By tailoring volunteer projects to include some form of "learn about the cause", "learn through direct handson experience" or demonstrating that volunteers are needed and thereby increasing their self-esteem, managers will best meet this motivation. Motivation related with altruism is also important, so managers can count on behaviour that will benefit others. On the other hand, career recognition motivation with a mean below the scale at midpoint shows that most of the volunteers are not worried about their "résumé," "career options" or "new contacts that might help business or career".

It is through this research that volunteers' sustained commitment will be better understood and fostered through adequate support in order that they maintain their contribution to society, so managers should consider all these motivations without forgetting that not every motivation will always be met, but by incorporating different objectives over time and acknowledging volunteers and the work they do it is possible to provide a positive and satisfying experience (Bruyere and Rappe 2007; Wei et al. 2012; Wymer 2012).

In terms of future research the study population could be expanded in order to include other organisations that work in the health area (e.g. organisations that focus on specific illnesses such as mental illness or epilepsy) or even to volunteers that work in different areas. We believe it would be interesting to verify whether volunteers' motivations are identical or diverse according to the subfield they work. It also would be useful to study the relationship between different types of motivations and volunteers' satisfaction, because when a volunteer is satisfied with his experience, the probability of continuing to collaborate with a certain organisation is higher (Cnaan and Goldberg-Glen 1991). As limitations we can mention that the absence of scales tested in the national context may have influenced the results because the scales used 
have been validated in other countries, possibly with very different characteristics from Portugal. Another limitation is related with the use of more sophisticated analysis approaches as, for example, confirmatory analysis and, finally, we should mention that eventually there are other variables, not considered here, that might influence volunteers' motivation. FCT Acknowledgments:The author João F. Proença thanks Fundação para a Ciência e Tecnologia R\&D Units. The author Teresa Proença thanks Fundação para a Ciência e Tecnologia (FCT Portugal) for financial support to CEF.UP by the Multi-Year Funding Program for R\&D Units.

\section{Appendix 1-Internal consistency}

Table 5 Internal consistency

\begin{tabular}{|c|c|c|}
\hline Item-Total statistics & $\begin{array}{l}\text { Corrected item- } \\
\text { Total correlation }\end{array}$ & $\begin{array}{l}\text { Cronbach's Alpha } \\
\text { if item deleted }\end{array}$ \\
\hline $\begin{array}{l}\text { 1. Volunteering can help me to get my foot in the door at a } \\
\text { place where I would like to work }\end{array}$ & 0.465 & 0.906 \\
\hline 2. My friends volunteer & 0.490 & 0.906 \\
\hline 3. I am concerned about those less fortunate than myself & 0.204 & 0.910 \\
\hline 4. People I'm close to want me to volunteer & 0.504 & 0.905 \\
\hline 6. People I know share an interest in community service & 0.501 & 0.905 \\
\hline $\begin{array}{l}\text { 7. No matter how bad I've been feeling, volunteering helps } \\
\text { me to forget about it }\end{array}$ & 0.562 & 0.904 \\
\hline 8. I am genuinely concerned about the particular group I am serving & 0.358 & 0.909 \\
\hline 9. By volunteering I feel less lonely & 0.504 & 0.906 \\
\hline 10. I can make new contacts that might help my business or career & 0.350 & 0.908 \\
\hline 12. I can learn more about the cause for which I am working & 0.574 & 0.904 \\
\hline 13. Volunteering increases my self-esteem & 0.667 & 0.902 \\
\hline 14. Volunteering allows me to gain a new perspective on things & 0.574 & 0.904 \\
\hline 15. Volunteering allows me to explore different career options & 0.496 & 0.906 \\
\hline 18. Volunteering let me learn things through direct hands on experience & 0.541 & 0.905 \\
\hline 19. I feel it is important to help others & 0.360 & 0.908 \\
\hline 20. Volunteering helps me work through by own personal problems & 0.609 & 0.903 \\
\hline 21. Volunteering will help me to succeed in my chosen profession & 0.480 & 0.906 \\
\hline 23. Volunteering makes me have more friends & 0.699 & 0.901 \\
\hline 24. Volunteering is a good escape from my own troubles & 0.581 & 0.904 \\
\hline 25. I can learn how to deal with a variety of people & 0.616 & 0.903 \\
\hline 26. Volunteering makes me feel needed & 0.399 & 0.907 \\
\hline 27. Volunteering makes me feel better about myself & 0.488 & 0.906 \\
\hline 28. Volunteering experience will look good on my résumé & 0.384 & 0.908 \\
\hline 29. Volunteering is a way to make new friends & 0.689 & 0.901 \\
\hline 30. I can explore my own strengths & 0.638 & 0.903 \\
\hline Cronbach's Alpha & & 0.909 \\
\hline
\end{tabular}




\section{References}

Alfansi L, Atmaja FT (2009) Service failure and complaint behavior in the public hospital industry: the Indonesian experience. J Nonprofit Public Sect Mark 21(3):309-325

Allison LD, Okun MA, Dutridge KS (2002) Assessing volunteer motives: a comparison of an open-ended probe and Likert Rating Scales. J Commun Appl Soc Psychol 12(4):243-255

Anderson MJ, Shaw RN (1999) A comparative evaluation of qualitative data analytic techniques in identifying volunteer motivation in tourism. Tour Manag 20(1):99-106

Batson CD, Ahmad N, Tsang J-A (2002) Four motives for community involvement. J Soc Issues 58 (3):429-445

Ben-Ner A, Hoomissen TV (1991) Nonprofits in the mixed economy: a demand and supply analysis. Ann Public Coope Econ 62(4):519-550

Bloom PN (1997) Field of marketing and public policy: introduction and overview. J Public Policy Mark 16 (1):126-128

Borzaga C, Santuari A (2003) New trends in the non-profit sector in Europe: the emergence of social entrepreneurship. In: OECD (ed) The non-profit sector in a changing economy. Organisation for Economic and Co-operation and Development (OECD), Paris

Braga A, Carvalho A (2010) A Influência dos Stakeholders no Processo de Tomada de Decisão em Entidades Locais Sem Fins Lucrativos-uma Revisão de Literatura. Paper presented at the $16^{\circ}$ Congresso da APDR, Funchal - Madeira - Portugal

Briggs E, Peterson M, Gregory G (2010) Toward a better understanding of volunteering for nonprofit organizations: explaining volunteers' pro-social attitudes. J Macromark 30(1):61-76

Bruyere B, Rappe S (2007) Identifying the motivations of environmental volunteers. J Environ Plan Manag 50(4):503-516

Burns DJ, Reid JS, Toncar M, Fawcett J, Anderson C (2006) Motivations to volunteer: the role of altruism. Int Rev Public NonProfit Mark 3(2):79-91

Burns DJ, Reid J, Toncar M, Anderson C, Wells C (2008) The effect of gender on the motivation of members of generation Y college students to volunteer. J Nonprofit Public Sect Mark 19(1):99-118

Bussell H, Forbes D (2002) Understanding the volunteer market: the what, where, who and why of volunteering. Int J Nonprofit Volunt Sect Mark 7(3):244-257

Celdrán M, Villar F (2007) Volunteering among older Spanish adults: does the type of organization matter? Educ Gerontol 33(3):237-251

Chacón F, Vecina ML (1999) Análisis de la Fiabilidad de un Cuestionario de Motivaciones del Voluntariado en Sida. Psicothema 11(1):211-223

Clary E, Snyder M, Ridge R, Copeland J, Stukas A, Haugen J, Miene P (1998) Understanding and assessing the motivations of volunteers: a functional approach. J Personal Soc Psychol 74(6):15161530

Cnaan RA, Goldberg-Glen RS (1991) Measuring motivation to volunteer in human services. J Appl Behav Sci 27(3):269-284

Cuskelly G, Harrington M (1997) Volunteers and leisure: evidence of marginal and career voluntarism in sport. World Leis Recreat 39(3):11-18

Cuskelly G, Hoye R, Auld C (2006) Working with volunteers in sport. Routledge, Abingdon

Edwards D (2005) Understanding the organization of volunteers at visitor attractions. University of Western Sydney, Sidney

Esmond J, Dunlop P (2004) Developing the volunteer motivation inventory. Lotterywest - CLAN WA, Perth

Farrell J, Johnston M, Twynam G (1998) Volunteer motivation, satisfaction, and management at an elite sporting competition. J Sport Manag 12(4):288-300

Ferreira S (2004) O Que Tem de Especial o Empreendedor Social? O Perfil de Emprego do Empresário Social em Portugal. Paper presented at the VIII Congreso Luso-Afro-Brasileiro de Ciências Sociais, Coimbra

Ferreira MR, Proença JF, Proença T (2008) As Motivações no Trabalho Voluntário. Rev Port Bras Gest 7 (3):43-53

Ferreira MR, Proença T, Proença JF (2012) Organisational influence on volunteer satisfaction and attitudes towards HRM practices: the case of hospital volunteers. Int Rev Public Nonprofit Mark 9(1):27-42

Franco RC, Sokolowski SW, Hairel EMH, Salamon LM (2005) O Sector Não Lucrativo Português Numa Perspectiva Comparada. http://www.jhu.edu/ cnp/pdf/Portugal Nat Rpt Portuguese.pdf (accessed in January 2008): Uniarte Gráfica 
Freeman RE (1984) Strategic management: a stakeholder approach. Harper Collins, Boston

Frisch MB, Gerrard M (1981) Natural helping systems: a survey of Red Cross volunteers. Am J Commun Psychol 9(5):567-579

Frooman J (1999) Stakeholder influence strategy. Acad Manag Rev 24(2):191-205

Grano C, Lucidi F, Zelli A, Violani C (2008) Motives and determinants of volunteering in older adults: an integrated model. J Aging and Hum Dev 67(4):305-326

Hair JF, Anderson RE, Tatham RL, Black WC (1998) Multivariate data analysis, 5th edn. Prentice Hall International

Horton-Smith D (1981) Altruism, volunteers and volunteerism. Nonprofit Volunt Sect Q 10(1):21-36

Hsieh J, Curtis KP, Smith AW (2008) Implications of stakeholder concept and market orientation in the US nonprofit arts context. Int Rev Public Nonprofit Mark 5(1):1-13

Hustinx L, Lammertyn F (2003) Collective and reflexive styles of volunteering: a sociological modernization perspective. Voluntas: Int J Volunt Nonprofit Organ 14(2):167-187

INE (2001) Número de Hospitais por Localização Geográfica (NUTS-2001) e Natureza institucional: INE

INE (2005) População Activa, Inquérito ao Emprego: INE

Kemp S (2002) The hidden workforce: volunteers' learning in the olympics. J Eur Ind Train 26(2-4):109-116

Kim M, Chelladurai P, Trail GT (2007) A model of volunteer retention in youth sport. J Sport Manag 21 (2):151-171

Latham GP (2007) Work motivation. Sage

Lee Y-J, Won D (2011) Attributes influencing college students' participation in volunteering: a conjoint analysis. Int Rev Public Nonprofit Mark 8(2):149-162

Lewis D (2001) Management of non-governmental development organizations: an introduction. Routledge, London

Manfredo MJ, Driver BL, Tarrant MA (1996) Measuring leisure motivation: a meta-analysis of the recreation experience preferences scales. J Leis Res 28(3):188-213

Marcuello CS, Marcuello CS, García IM (2009) Una Aproximación al Voluntariado en Europa. Panorama Social 9(Primer Semestre): 98-113

Maslow A (1943) A theory of human motivation. Psychol Rev 50(4):370-396

Maslow A (1987) Motivation and personality, 3rd edn. Addison-Wesley, New York

Meier S, Stutzer A (2004) Is volunteering rewarding in itself? IZA Discussion Paper 1045:1-32

Meyer J, Gagné M (2008) Employee engagement from a self-determination theory perspective. Ind Organ Psychol 1(1):60-62

Monroe KR (1996) The heart of altruism. Princeton University Press

Musick MA, Wilson J (2008) Volunteers - a social profile. Indiana University Press, Bloomington

OECD (2003) The non-profit sector in a changing economy. Organisation for Economic and Co-operation and Development (OECD), Paris

Okun MA, Schultz A (2003) Age and motives for volunteering: testing hypotheses derived from socioemotional selectivity theory. Psychol Aging 18(2):231-239

Okun MA, Barr A, Herzog AR (1998) Motivation to volunteer by older adults: a test of competing measurement models. Psychol Aging 13(4):608-621

Papadakis K, Griffin T, Frater J (2004) Understanding volunteers' motivations. Paper presented at the Northeastern Recreation Research Symposium, Newtown

Pestana MH, Gageiro JN (2003) Análise de Dados para Ciências Sociais. Edições Sílabo, Lisboa

Phillips M (1982) Motivation and expectation in successful volunteerism. Nonprofit and Volunt Sect Q 11 $(2 / 3): 118-125$

Pope JA, Isely ES, Asamoa-Tutu F (2009) Developing a marketing strategy for nonprofit organizations: an exploratory study. J Nonprofit Public Sect Mark 21(2):184-201

Prouteau L, Wolff F-C (2008) On the relational motive for volunteer work. J Econ Psychol 29(3):314-335

Raman P, Pashupati K (2002) Turning good citizens into even better ones: the impact of program characteristics and motivations on service learning outcomes. J Nonprofit Public Sect Mark 10 (2):187-206

Randle M, Dolnicar S (2009) Not just any volunteers: segmenting the market to attract the high contributors. J Nonprofit Public Sect Mark 21(3):271-282

Rhoden S, Ineson EM, Ralston R (2009) Volunteer motivation in heritage railways: a study of the West Somerset Railway volunteers. J Herit Tour 4(1):19-36

Slaughter L, Home R (2004) Motivations of long term volunteers: human service vs events. Paper presented at the Las Vegas International Hospitality \& Convention Summit, Las Vegas

Soupourmas F, Ironmonger D (2002) Giving time: the economic and social value of volunteering in Victoria. Department of Human Services, Victoria 
Tapp JT, Spanier D (1973) Personal characteristics of volunteer phone counselors. J Consult Clin Psychol 41(2):245-250

Trogdon SE (2005) A study of parks and recreation citizen board members in North Carolina and their motivation for participation. North Carolina State University

Wei Y, Donthu N, Bernhardt KL (2012) Volunteerism of older adults in the United States. Int Rev Public Nonprofit Mark 9(1):1-18

Wilson A, Pimm G (1996) The tyranny of the volunteer: the care and feeding of voluntary workforce. MCB University Press 34:24-40

Wymer W (2011) The implications of sex differences on volunteer preferences. Voluntas: Int J Volunt Nonprofit Organ 22(4):831-851

Wymer W (2012) Gender differences in social support in the decision to volunteer. Int Rev Public Nonprofit Mark 9(1):19-26

Yavas U, Riecken G (1985) Can volunteers be targeted? J Acad Mark Sci 13(2):218-228

Yoshioka CF, Brown WA, Ashcraft RF (2007) A functional approach to senior volunteer and non-volunteer motivations. Int J Volunt Admin XXIV(5):31-43 